
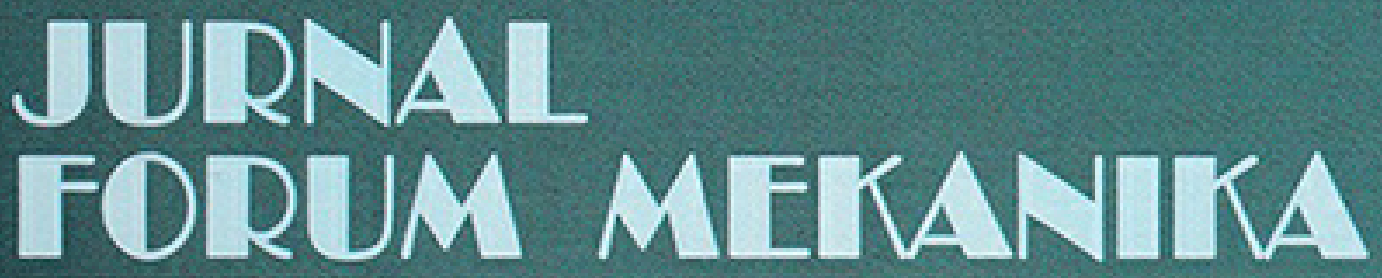

Volume 6 - Nomor 2 November 2017 ISSN : 2356-1491

ANALISIS RUMAH KABEL BAWAH TANAH PADA PROYEK PEKERJAAN JARINGAN UTILITAS SKTT 150 KV PLUMPANG - GAMBIR DYAH PRATIWI KUSUMASTUTI; IRMA SEPRIYANNA

STUDI KOMPARASI ANTARA PRACETAK MASIF DAN FLY SLAB STUDI KASUS: STRUKTUR GEDUNG RUSUNAWA SURAKARTA BUDI WICAKSONO

SISTEM DRAINASE ALIRAN BAWAH TANAH UNTUK DAERAH RAWAN LONGSOR (STUDI KASUS SUB DAS SUNGAI CIKAPUNDUNG, BANDUNG) ENDAH LESTARI

ANALISA STATISTIK DEBIT BANIIR DAN DEBIT ANDALAN SUNGAI KOMERING SUMATERA SELATAN DEVITA MAYASARI

STUDI EKSPERIMENTAL KUAT LENTUR BAJA PROFIL I KOMPAK SIMETRIS GANDA BERDASARKAN RSNI 03-1729-201X

DICKI DIAN PURNAMA; AKHMAD AMINULLAH; MUSLIKH

PENGGUNAAN PASIR LAUT TERHADAP KUAT TEKAN BETON KOTA BENGKULU TOMMYIDUWIN

ANALISA PENGARUH ADMIXTURE TERHADAP ABU TERBANG (FLY ASH) DAN BOTTOM ASH

TRI YUHANAH; NOVIA ADE MANDASARI

ANALISA KINERJA PERSIMPANGAN BERSINYAL PADA PERSIMPANGAN ANGKATAN 66 DAN RUAS JALAN R. SOEKAMTO KOTA PALEMBANG YULES PRAMONA ZULKARNAIN; IRMA INDRIANI 


\title{
ANALISA STATISTIK DEBIT BANJIR DAN DEBIT ANDALAN SUNGAI KOMERING SUMATERA SELATAN
}

\author{
DEVITA MAYASARI \\ Jurusan Teknik Sipil, Sekolah Tinggi Teknik PLN Jakarta \\ E-mail : devita.maya@ymail.com
}

\begin{abstract}
Abstrak
Debit aliran sungai merupakan salah satu parameter hidrologi yang sangat penting bagi pengelolaan sumber daya air karena data debit sungai diperlukan untuk keperluan di masa mendatang dengan asumsi karakteristik proses tidak berubah. Sungai Komering merupakan salah satu sungai terbesar di Provinsi Sumatera Selatan yang cukup berperan besar dalam kehidupan masyarakat yang berada di wilayah Sub DAS Komering. Besarnya debit banjir dan debit andalan Sungai Komering sangatlah penting untuk diperhitungkan, dengan menganalisa debit banjir dapat dilakukan perancangan bangunan pengelola banjir, sedangkan dengan menganalisa debit andalan dapat dilakukan perencanaan pemanfaatan air sungai. Penelitian berdasarkan pengumpulan data-data sekunder yang diperoleh dari Dinas Pekerjaan Umum Sumatera Selatan dan Balai Besar Wilayah Sungai Sumatera VIII, berupa data debit Sungai Komering tahun 2000 hingga tahun 2010 dan peta-peta yang dibutuhkan untuk mengetahui daerah yang dikaji. Semua data tersebut dikorelasikan dimana analisa yang dimaksudkan untuk mengetahui statistik debit banjir dan debit andalan di Sungai Komering. Hasil analisis diperoleh bahwa distribusi yang dapat digunakan untuk memprediksi debit banjir di Sungai Komering adalah distribusi Gumbel dengan perkiraan debit banjir untuk masing-masing kala ulang yaitu kala ulang 2 tahun sebesar 1.007,57 m³ kala ulang 25 tahun sebesar 2.137,50 $\mathrm{m}^{3} / \mathrm{dt}$, kala ulang 50 tahun sebesar 2.418,15 $\mathrm{m}^{3} / \mathrm{dt}$, dan kala ulang 100 tahun sebesar 2.696,73 m²/dt. Berdasarkan analisa debit andalan dengan Metode Bulan Dasar Perencanaan bahwa distribusi Log Pearson III dapat dipakai untuk menganalisis debit andalan di Sungai Komering. Debit andalan tertinggi sebesar 226,20 $\mathrm{m}^{3} /$ dt dan debit andalan terendah sebesar $62,08 \mathrm{~m}^{3} / \mathrm{dt}$.
\end{abstract}

Kata kunci : debit banjir, debit andalan.

\begin{abstract}
River flow discharge is one of the most important hydrological parameters for the management of water resources because river flow data is required for future pusposes assuming the process characteristics are unchanged. Komering River is one of the largest rivers in the Province South Sumatra which is quite a big role in the lives of people who are in the sub Komering watershed. The magnitude of the flood discharge and dependable flow Komering River is very important to to be taken into account, by analyzing the flood discharge can be done flood management, while by analyzing the dependable flow can be done planning river water utilization. The research based on the collection of secondary data obtained from Departemen Pekerjaan Umum Sumatera Selatan and Balai Besar Wilayah Sungai Sumatera VIII, discharge data from 2000 to 2010 and maps needed to know the study area. All the data are correlated where the analysis is intended to determine the statistics of flood discharge and dependable flow Komering River. From the results of analyzes obtained that the distribution can be used to predict flooding in the river discharge is Gumbel distribution with estimate the flood discharge for 2 years return period $1007.57 \mathrm{~m}^{3} / \mathrm{dt}$, for 5 years return period $1459.79 \mathrm{~m}^{3} / \mathrm{dt}$, for 10 years return period $1759.20 \mathrm{~m}^{3} / \mathrm{dt}$, for 25 years return peiod $2137.50 \mathrm{~m}^{3} / \mathrm{dt}$, for 50 years return period $2418.15 \mathrm{~m}^{3} / \mathrm{dt}$, and for 100 years return period $2696.73 \mathrm{~m}^{3} / \mathrm{dt}$. Based on analysis of dependable flow, Month Basic Plan Method, that Log Pearson III distribution can be used to analyze River Komering dependable flow. The highest dependable flow of is $226.20 \mathrm{~m}^{3} / \mathrm{dt}$ and the lowest dependable flow is $62.08 \mathrm{~m}^{3} / \mathrm{dt}$.
\end{abstract}

Key words : discharge, flood discharge, dependable flow

\section{Latar Belakang}

Debit aliran sungai merupakan salah satu parameter hidrologi yang sangat penting bagi pengelolaan sumber daya air karena data debit sungai dan peramalannya ini sangat diperlukan untuk masa mendatang dengan asumsi karakteristik proses tidak berubah. Data debit sungai yang tercatat adalah data sampel dari debit aliran sungai karena secara faktual tidaklah mungkin pada suatu sungai memiliki data populasi debit sungai yang mengandung data debit sejak sungai tersebut ada hingga sungai tersebut tiada. Data debit yang diolah merupakan data jangka panjang dan merupakan deret berkala yang nilainya menunjukkan gerakan yang berjangka panjang dan mempunyai kecenderungan menuju ke satu arah, arah menaik atau menurun. Untuk 
menggambarkan karakteristik debit tersebut dilakukanlah perhitungan dengan metode statistik.

Dalam analisa statistik debit aliran sungai, diperlukan data debit maksimum, rata-rata, dan minimum pada jangka waktu tertentu. Debit maksimum diperlukan untuk menganalisis debit banjir yang akan digunakan untuk melakukan perancangan bangunan pengelola banjir. Sementara itu, untuk menganalisis debit andalan, yaitu debit yang tersedia sepanjang tahun dengan besarnya resiko kegagalan tertentu, diperlukan data debit ratarata. Dari keempat metode perhitungan debit andalan, pada penelitian ini hanya dilakukan satu metode, yaitu metode Bulan Dasar Perencanaan karena metode ini lebih bisa menggambarkan keandalan pada musim kemarau dan penghujan. Debit andalan diperlukan untuk perencanaan pemanfaatan air untuk berbagai macam keperluan, seperti keperluan air minum, industri, irigasi, dan PLTA.

Lokasi penelitian ini dilakukan di Sungai Komering yang terletak di Provinsi Sumatera Selatan. Pada Sungai Komering telah dilakukan penelitian data debit di bendung dan saluran, namun belum ada penelitian mengenai analisa statistik debit banjir dan debit andalan di sungai tersebut. Analisa statistik debit banjir dan debit andalan Sungai Komering mampu menirukan data debit historis dan mampu meramalkan debit di Sungai Komering untuk satu periode data ke depan sehingga dapat menentukan debit banjir dan debit andalan yang digunakan untuk perencanaan bangunan air dan pengelolaan keperluan air di masa mendatang.

\section{Landasan Teori}

\section{Pengertian Sungai}

Sebagian besar air hujan yang turun ke permukaan tanah mengalir ke tempat-tempat yang lebih rendah dan setelah mengalami bermacammacam perlawanan akibat gaya berat, akhirnya melimpah ke danau atau ke laut. Suatu alur yang panjang di atas permukaan bumi tempat mengalirnya air berasal dari hujan disebut alur sungai. Bagian yang senantiasa tersentuh aliran ini disebut alur sungai. Dan perpaduan antara sungai dan aliran air di dalamnya disebut sungai.

Sungai didefinisikan sebagai aliran terbuka dengan ukuran geometrik (tampak lintang, profil memanjang dan kemiringan lembah) berubah seiring waktu, tergantung pada debit, material dasar tebing, serta jumlah dan jenis sedimen yang terangkut oleh air

\section{Wilayah Sungai Musi dan Sungai Komering}

Sungai Musi merupakan sungai terpanjang di pulau Sumatera dan membelah kota Palembang menjadi dua bagian. Daerah aliran sungai Musi terdiri dari sebelas sub DAS, yaitu Sub DAS Lematang, sub DAS Komering, sub DAS Ogan, sub
DAS Kikim, sub DAS Lakitan, sub DAS Batanghari Leko, sub DAS Semangus, sub DAS Beliti, sub DAS Rawas, sub DAS Musi Hilir, dan sub DAS Musi Hulu

Luas seluruh Kabupaten/Kota di Provinsi Sumatera Selatan dan 2 Kabupaten di Provinsi Bengkulu adalah $89.070,26 \mathrm{~km}^{2}$ sedang areal yang berada di wilayah Sungai Musi sebesar 58.625,38 $\mathrm{km}^{2}(65,81 \%)$. Bagian hulu wilayah sungai Musi yang meliputi 8 Kabupaten/Kota menempati areal seluas $25.823,33 \mathrm{~km}^{2}$ (44.05\% dari luas seluruh wilayah sungai Musi), bagian tengah meliputi 5 kabupaten/Kota $\left(21.890,54 \mathrm{~km}^{2}\right.$ atau $37,34 \%$ dari seluruh wilayah sungai Musi) dan bagian hilir yang meliputi 4 Kabupaten/Kota $\left(10.911,52 \mathrm{~km}^{2}\right.$ atau $18,61 \%$ dari seluruh wilayah sungai Musi).

Sungai Komering merupakan salah satu dari sebelas sub daerah aliran sungai yang terdapat pada daerah aliran sungai Musi. Sungai yang berhulu di Danau Ranau ini memiliki panjang sekitar 4,5 kilometer dan lebar rata-rata 236 meter.

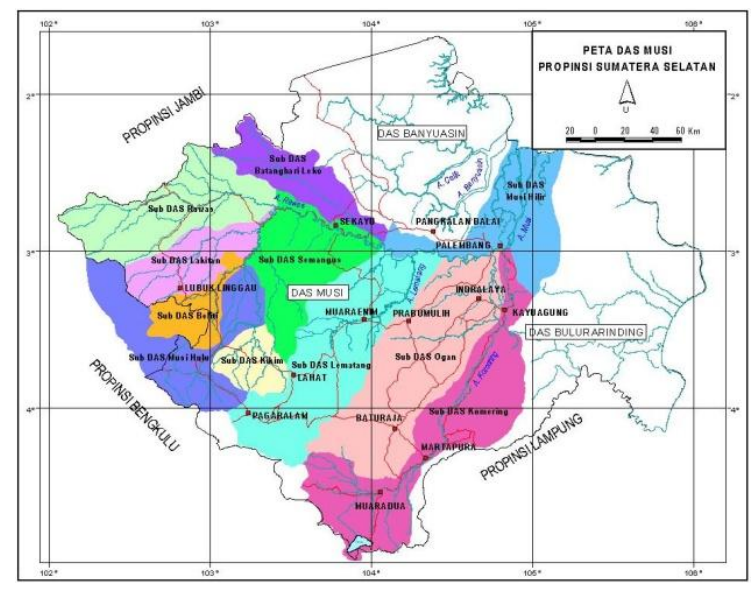

Gambar 1 Peta DAS Musi
Sumber : Balai Besar Wilayah Sungai Sumatera VIII (2011)

\section{Debit Aliran Sungai}

Debit aliran diperoleh dengan mengalikan luas tampang aliran dan kecepatan aliran. Kedua parameter ini diukur pada suatu tampang lintang sungai. Luas tampang aliran diperoleh dengan mengukur elevasi permukaan air dan dasar sungai. Kecepatan aliran diukur dengan menggunakan alat ukur kecepatan seperti current meter, pelampung, atau peralatan lain.

\section{Debit Banjir}

Debit banjir merupakan banyaknya air yang mengakibatkan banjir yang mengalir per satuan waktu dari sumber mata air. Debit banjir pada setiap profil sungai merupakan data yang paling penting untuk perencanaan, perbaikan, dan pengaturan sungai. Debit banjir diperoleh dari debit maksimum yang berguna untuk keperluan perencanaan penanggulangan banjir di masa mendatang. Untuk 
menentukan debit banjir, terdiri beberapa tahapan yaitu dengan histogram, menentukan parameter statistik, melakukan analisa frekuensi, dan melakukan uji kecocokan.

a. Histogram dan Poligon Frekuensi

Histogram merupakan grafik batang dari distribusi frekuensi dan polygon frekuensi merupakan grafik garisnya. Bentuk-bentuk distribusi frekuensi adalah :

1. Simetris atau berbentuk lonceng, ciri-cirinya ialah nilai variabel di samping kiri dan kanan yang berjarak sama terhadap titik tengah mempunyai frekuensi yang sama. Dinamakan juga distribusi normal.

2. Non-simetris/condong, yaitu condong ke kanan (kocondongan positif), condong ke kiri (kecondongan negatif)

3. Bentuk $\mathbf{J}$ atau $\mathbf{J}$ terbalik, ciri-cirinya ialah salah satu nilai ujung kurva memiliki frekuensi maksimum.

4. Bentuk U, dengan ciri kedua ujung kurva memiliki frekuensi maksimum.

5. Bimodal, dengan ciri mempunyai dua maksimal.

6. Multimodal, dengan ciri mempunyai lebih dari dua maksimal.

7. Uniform, terjadi bila nilai-nilai variabel dalam suatu interval mempunyai frekuensi yang sama.

b. Parameter Statistik

Adapun parameter-parameter statistik tersebut antara lain :

\section{Nilai rata-rata}

$$
\bar{X}=\frac{\sum X_{i}}{n}
$$

dengan :

$\bar{X}=$ nilai rata-rata debit

$X_{i}=$ nilai debit ke-i

$\mathrm{n}=$ jumlah data

\section{Standar deviasi}

$$
S=\left[\frac{\sum_{i=1}^{n}\left(X_{i}-\bar{X}\right)^{2}}{n-1}\right]^{\frac{1}{2}}
$$

dengan:

$\mathrm{S}=$ standar deviasi

$X_{i}=$ nilai debit ke-i

$\bar{X}=$ nilai rata-rata debit

$n=$ jumlah data

\section{Koefisien skewness}

$C_{S}=\frac{n \sum_{i=1}^{n}\left(X_{i}-\bar{X}\right)^{3}}{(n-1)(n-2) S^{3}}$

dengan:

$C_{s}=$ koefisien skewness
$X_{i}=$ nilai debit ke-i

$\bar{X}=$ nilai rata-rata debit

$n=$ jumlah data

$\mathrm{S}=$ standar deviasi

\section{Koefisien kurtosis}

$C_{K}=\frac{\frac{1}{n} \sum_{i=1}^{n}\left(X_{i}-\bar{X}\right)^{4}}{S^{4}}$

dengan :

$C_{K}=$ koefisien kurtosis

$X_{i}=$ nilai debit ke-i

$\bar{X}=$ nilai rata-rata debit

$n$ = jumlah data

$\mathrm{S}=$ standar deviasi

\section{Koefisien variasi}

$$
C_{V}=\frac{S}{\bar{X}}
$$

dengan :

$\mathrm{Cv}=$ koefisien variasi

$\bar{X}=$ nilai rata-rata debit

$S=$ standar deviasi

c. Analisis Frekuensi

Analisis frekuensi merupakan prakiraan (forecasting), dalam arti probabilitas untuk terjadinya suatu peristiwa hidrologi yang berfungsi sebagai dasar perhitugan perencanaan hidrologi untuk antisipasi setiap kemungkinan yang akan terjadi. Analisis frekuensi ini dilakukan dengan menggunakan sebaran kemungkinan teori probability distribution. Ada beberapa macam distribusi yang semuanya dapat dibagi menjadi dua yaitu distribusi diskret dan distribusi kontinyu. Yang termasuk distribusi diskret adalah binomial dan poisson, sedangkan yang termasuk distribusi kontinyu adalah, Normal, Log Normal, Gama, Beta, Pearson, dan Gumbel. Pedoman umum penggunaan distribusi dapat dilihat pada Tabel 1 .

Tabel 1. Pedoman Umum Penggunaan Distribusi

\begin{tabular}{|l|l|l|}
\hline No. & \multicolumn{1}{|c|}{ Jenis Sebaran } & \multicolumn{1}{|c|}{ Syarat } \\
\hline 1 & Normal & $\mathrm{C}_{\mathrm{s}}=0 ; \mathrm{C}_{\mathrm{k}}=3$ \\
\hline 2 & Log Normal & $\mathrm{C}_{\mathrm{s}}=1,104 ; \mathrm{C}_{\mathrm{k}}=5,24$ \\
\hline 3 & Gumbel & $\mathrm{C}_{\mathrm{s}} \approx 1,4 ; \mathrm{C}_{\mathrm{k}} \approx 5,4002$ \\
\hline 4 & Log Pearson Tipe III & $\mathrm{C}_{\mathrm{s}} \neq 0 ; \mathrm{C}_{\mathrm{V} 1}=0,3$ \\
\hline
\end{tabular}

Sumber : Soewarno (1995)

\section{Distribusi Normal}

$X t=\bar{X}+K \operatorname{Tr} . S x$

dengan:

$\mathrm{Xt}=$ debit rencana

$\bar{X}=$ debit maksimum rata-rata 
$\mathrm{Sx}=$ standar deviasi

$\mathrm{KTr}=$ faktor frekuensi (Tabel 2)

\section{Distribusi Log Normal}

$\log X t=\overline{\log X}+K \operatorname{Tr} . S_{\log x}$

dengan :

$\log \mathrm{Xt}=\log$ aritmik debit

$\overline{\log X}=\log$ aritma debit rata-rata $=\frac{1}{n} \sum_{n=1}^{n} \log X$

$S_{\log x}=$ standar deviasi $\sqrt{\frac{1}{n-1} \sum\left(\log X_{i}-\overline{\log X}\right)^{2}}$

$\mathrm{KTr}=$ Standar variabel untuk periode ulang $\mathrm{T}$ tahun (Tabel 3)

\section{Distribusi Gumbel}

$$
X t=\bar{X}+\frac{(Y t-Y n)}{S_{n}} S x
$$

dengan:

$\mathrm{Xt}=$ debit rencana

$\bar{X}=$ debit rata-rata

$\mathrm{Yt}=$ reduced variable $=\mathrm{Y}_{\mathrm{T}}=-\ln \left[\ln \left(\frac{\mathrm{Tr}}{\mathrm{Tr}-1}\right)\right]$

$\mathrm{Yn}=$ reduced mean, merupakan fungsi dari banyaknya data (n) (Tabel 4)

$\mathrm{Sn}=$ reduced standar deviasi, fungsi dari banyaknya data (n) (Tabel 5)

$\mathrm{Sx}=$ standar deviasi

$\mathrm{Xi}=$ debit ke-i

$\mathrm{n}=$ banyak data

\section{Distribusi Log Pearson III}

$\log \left(X_{T}\right)=\overline{\log (X)}+K \cdot S d$

dengan:

Log Xt = logaritma debit

$\overline{\log (X)}=$ harga rata-rata logaritmik

$\mathrm{K} \quad$ = faktor frekuensi (Tabel 6 dan 7)

$\mathrm{S} \quad=$ standar deviasi

Tabel 2. Nilai Variasi Gauss

\begin{tabular}{|c|c|c|c|}
\hline No. & Tr (tahun) & KTr & Peluang \\
\hline 1 & 1.001 & -3.05 & 0.999 \\
\hline 2 & 1.005 & -2.58 & 0.995 \\
\hline 3 & 1.010 & -2.33 & 0.990 \\
\hline 4 & 1.050 & -1.64 & 0.950 \\
\hline 5 & 1.110 & -1.28 & 0.900 \\
\hline 6 & 1.250 & -0.84 & 0.800 \\
\hline 7 & 1.330 & -0.67 & 0.750 \\
\hline 8 & 1.430 & -0.52 & 0.700 \\
\hline 9 & 1.670 & -0.25 & 0.600 \\
\hline 10 & 2.000 & 0.00 & 0.500 \\
\hline 11 & 2.500 & 0.25 & 0.400 \\
\hline 12 & 3.330 & 0.52 & 0.300 \\
\hline 13 & 4.000 & 0.67 & 0.250 \\
\hline 14 & 5.000 & 0.84 & 0.200 \\
\hline 15 & 10.000 & 1.28 & 0.100 \\
\hline 16 & 25.000 & 1.64 & 0.040 \\
\hline 17 & 50.000 & 2.05 & 0.020 \\
\hline 18 & 100.000 & 2.33 & 0.010 \\
\hline 19 & 200.000 & 2.58 & 0.005 \\
\hline 20 & 500.000 & 2.88 & 0.002 \\
\hline 21 & 1000.000 & 3.09 & 0.001 \\
\hline
\end{tabular}

Sumber : Soewarno (1995)
Tabel 3. Standar Variabel (KTr)

\begin{tabular}{|c|c|c|c|c|c|c|c|}
\hline \multirow{4}{*}{$\begin{array}{c}\text { Variasi } \\
\text { Coef. } \\
\text { CV }\end{array}$} & \multicolumn{7}{|c|}{ RE TURN PE RIODE (YEAR) } \\
\hline & 2 & 5 & , & ? & 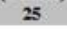 & 50 & 100 \\
\hline & \multicolumn{7}{|c|}{ EXCEE DE NCE PROBABILITY } \\
\hline & 0.500 & 0.200 & 0.100 & 0.050 & 0.040 & 0.020 & 0.010 \\
\hline 0.05 & -0.0250 & 0.8334 & 1.2965 & 1.6863 & 1.7609 & 2.1341 & 2.4570 \\
\hline 0.10 & -0.0496 & 0.8222 & 1.3078 & 1.7247 & 1.8061 & 2.2130 & 2.5489 \\
\hline 0.15 & -0.0738 & 0.8085 & 1.3156 & 1.7598 & 1.8482 & 2.2899 & 2.2607 \\
\hline 0.20 & -0.0971 & 0.7926 & 1.3200 & 1.7911 & 1.8866 & 2.3640 & 2.7716 \\
\hline 0.25 & -0.1194 & 0.7746 & 1.3209 & 1.8183 & 1.9206 & 2.4318 & 2.8805 \\
\hline 0.30 & -0.1406 & 0.7647 & 1.3183 & 1.8414 & 1.9514 & 2.5015 & 2.9866 \\
\hline 0.35 & -0.1604 & 0.7333 & 1.3126 & 1.8602 & 1.9775 & 2.5638 & 3.0890 \\
\hline 0.40 & -0.1788 & 0.7100 & 1.3037 & 1.8746 & 1.9990 & 2.6212 & 3.1870 \\
\hline 0.45 & -0.1957 & 0.6870 & 1.2920 & 1.8848 & 2.0162 & 2.6731 & 3.2799 \\
\hline 0.50 & -0.2111 & 0.6626 & 1.2778 & 1.8909 & 2.0291 & 2.7202 & 3.367. \\
\hline 0.55 & -0.2251 & 0.6379 & 1.2613 & 1.8931 & 2.0378 & 2.7613 & 3.4488 \\
\hline 0.60 & -0.2375 & 0.6129 & 1.2428 & 1.8915 & 2.1475 & 2.7971 & 3.5211 \\
\hline 0.65 & -0.2185 & 0.5879 & 1.2226 & 1.8866 & 2.0435 & 2.8279 & 3,3930 \\
\hline 0.70 & -0.2582 & 0.5631 & 1.2011 & 1.8786 & 2.0410 & 2.8532 & 3.3663 \\
\hline 0.75 & -0.2667 & 0.5387 & 1.1784 & 1.8677 & 2.0353 & 2.8735 & 3.7118 \\
\hline 0.80 & -0.2739 & 0.5118 & 1.1548 & 1.8543 & 2.0268 & 2.8891 & 3.7617 \\
\hline 0.85 & -0.2801 & 0.4914 & 1.1306 & 1.8388 & 2.0157 & 2.9002 & 3.8056 \\
\hline 0.90 & -0.2852 & 0.4686 & 1.1060 & 1.8212 & 2.0012 & 2.9010 & 3.8137 \\
\hline 0.95 & -0.2895 & 0.4466 & 1.0810 & 1.8021 & 1.9868 & 2.9103 & 3.8762 \\
\hline 1.00 & -0.2929 & 0.4254 & 1.0560 & 1.7815 & 1.9681 & 2.9010 & 3.9035 \\
\hline
\end{tabular}

Sumber : Soewarno (1995)

Tabel 4. Reduced Mean (Yn)

\begin{tabular}{|c|c|c|c|c|c|c|c|c|c|c|}
\hline $\mathrm{n}$ & 0 & 1 & 2 & 3 & 4 & 5 & 6 & 7 & 8 & 9 \\
\hline 10 & 0,4952 & 0,4996 & 0,5035 & 0,507 & 0,51 & 0,5128 & 0,5157 & 0,5181 & 0,5202 & 0,522 \\
\hline 20 & 0,5236 & 0,5252 & 0,5268 & 0,5283 & 0,5296 & 0,53 & 0,582 & 0,5882 & 0,5343 & 0,5353 \\
\hline 30 & 0,5363 & 0,5371 & 0,538 & 0,5388 & 0,5396 & 0,54 & 0,541 & 0,5418 & 0,5424 & 0,543 \\
\hline 40 & 0,5463 & 0,5442 & 0,5448 & 0,5453 & 0,5458 & 0,5468 & 0,5468 & 0,5473 & 0,5477 & 0,5481 \\
\hline 50 & 0,5485 & 0,5489 & 0,5493 & 0,5497 & 0,5501 & 0,5504 & 0,5508 & 0,5511 & 0,5515 & 0,5518 \\
\hline 60 & 0,5521 & 0,5524 & 0,5527 & 0,553 & 0,5533 & 0,5535 & 0,5538 & 0,554 & 0,5543 & 0,5545 \\
\hline 70 & 0,5548 & 0,555 & 0,5552 & 0,5555 & 0,5557 & 0,5559 & 0,5561 & 0,5563 & 0,5565 & 0,5567 \\
\hline 80 & 0,5569 & 0,557 & 0,5572 & 0,5574 & 0,5576 & 0,5578 & 0,558 & 0,5581 & 0,5583 & 0,5585 \\
\hline 90 & 0,5586 & 0,5587 & 0,5589 & 0,5591 & 0,5592 & 0,5593 & 0,5595 & 0,5596 & 0,8898 & 0,5599 \\
\hline 100 & 0,56 & & & & & & & & & \\
\hline
\end{tabular}

Sumber : C.D. Soemarto (1999)

Tabel 5. Reduced Standar Deviation (Sn)

\begin{tabular}{|c|c|c|c|c|c|c|c|c|c|c|}
\hline $\mathrm{n}$ & 0 & 1 & 2 & 3 & 4 & 5 & 6 & 7 & 8 & 9 \\
\hline 10 & 0,9496 & 0,9676 & 0,9833 & 0,9971 & 1,0095 & 1,0206 & 1,0316 & 1,0411 & 1,0493 & 1,0565 \\
\hline 20 & 1,0628 & 1,0696 & 1,0754 & 1,0811 & 1,0864 & 1,0915 & 1,0961 & 1,1004 & 1,1047 & 1,108 \\
\hline 30 & 1,1124 & 1,1159 & 1,1193 & 1,226 & 1,1255 & 1,1285 & 1,1313 & 1,1339 & 1,1363 & 1,1388 \\
\hline 40 & 1,1413 & 1,1436 & 1,1458 & 1,148 & 1,1499 & 1,1519 & 1,1538 & 1,1557 & 1,1574 & 1,159 \\
\hline 50 & 1,1607 & 1,1623 & 1,1638 & 1,1658 & 1,1667 & 1,1681 & 1,1696 & 1,1708 & 1,1721 & 1,1734 \\
\hline 60 & 1,1747 & 1,1759 & 1,177 & 1,1782 & 1,1793 & 1,1803 & 1,1814 & 1,1824 & 1,1834 & 1,1844 \\
\hline 70 & 1,1854 & 1,1863 & 1,1873 & 1,1881 & 1,189 & 1,1898 & 1,1906 & 1,1915 & 1,1923 & 1,193 \\
\hline 80 & 1,1938 & 1,1945 & 1,1953 & 1,1959 & 1,1967 & 1,1973 & 1,198 & 1,1987 & 1,1994 & 1,2001 \\
\hline 90 & 1,2007 & 1,2013 & 1,2026 & 1,2032 & 1,2038 & 1,2044 & 1,2046 & 1,2049 & 1,2055 & 1,206 \\
\hline 100 & 1,2065 & & & & & & & & & \\
\hline
\end{tabular}

Sumber : C.D. Soemarto, 1999 
Tabel 6. Faktor Frekuensi (KTr) Log Pearson III Untuk Cs Negatif

\begin{tabular}{|c|c|c|c|c|c|c|c|}
\hline \multirow{4}{*}{$\begin{array}{c}\text { Skew } \\
\text { Coef. } \\
\mathrm{C}^{\prime} \\
\mathrm{Cs}^{\prime}\end{array}$} & \multicolumn{7}{|c|}{ RETURN PERIODE(YEAR) } \\
\hline & 2 & 5 & 10 & 25 & 50 & 100 & 200 \\
\hline & \multicolumn{7}{|c|}{ EXCEEDENCE PROBABILITY } \\
\hline & 0.500 & 0.200 & 0.100 & 0.040 & 0.020 & 0.010 & 0.005 \\
\hline-3.0 & 0.396 & 0.636 & 0.666 & 0.666 & 0.666 & 0.667 & 0.667 \\
\hline-2.9 & 0.390 & 0.651 & 0.681 & 0.683 & 0.689 & 0.690 & 0.690 \\
\hline-2.8 & 0.384 & 0.666 & 0.702 & 0.712 & 0.714 & 0.714 & 0.714 \\
\hline-2.7 & 0.376 & 0.681 & 0.747 & 0.738 & 0.740 & 0.740 & 0.741 \\
\hline-2.6 & 0.368 & 0.696 & 0.771 & 0.764 & 0.768 & 0.769 & 0.769 \\
\hline-2.5 & 0.360 & 0.711 & 0.795 & 0.793 & 0.798 & 0.799 & 0.800 \\
\hline-2.4 & 0.351 & 0.725 & 0.819 & 0.823 & 0.830 & 0.832 & 0.833 \\
\hline-2.3 & 0.341 & 0.739 & 0.844 & 0.855 & 0.864 & 0.867 & 1.869 \\
\hline-2.2 & 0.330 & 0.752 & 0.869 & 0.888 & 0.900 & 0.905 & 0.907 \\
\hline-2.1 & 0.319 & 0.765 & 0.895 & 0.923 & 0.939 & 0.946 & 0.949 \\
\hline-2.0 & 0.307 & 0.777 & 0.920 & 0.959 & 0.980 & 0.990 & 0.993 \\
\hline-1.9 & 0.294 & 0.788 & 0.945 & 0.996 & 1.023 & 1.038 & 1.044 \\
\hline-1.8 & 0.282 & 0.799 & 0.970 & 1.035 & 1.069 & 1.087 & 1.097 \\
\hline-1.7 & 0.268 & 0.808 & 0.884 & 1.075 & 1.116 & 1.140 & 1.15 \\
\hline-1.6 & 0.254 & 0.817 & 0.994 & 1.116 & 1.166 & 1.197 & 1.216 \\
\hline-1.5 & 0.240 & 0.825 & 1.018 & 1.157 & 1.217 & 1.256 & 1.282 \\
\hline-1.4 & 0.225 & 0.832 & 1.041 & 1.198 & 1.270 & 1.318 & 1.351 \\
\hline-1.3 & 0.210 & 0.838 & 1.064 & 1.240 & 1.324 & 1.383 & 1.424 \\
\hline-1.2 & 0.195 & 0.844 & 1.086 & 1.282 & 1.379 & 1.449 & 1.501 \\
\hline-1.1 & 0.180 & 0.848 & 1.107 & 1.324 & 1.435 & 1.518 & 1.581 \\
\hline-1.0 & 0.164 & 0.852 & 1.128 & 1.366 & 1.492 & 1.588 & 1.664 \\
\hline-0.9 & 0.148 & 0.854 & 1.147 & 1.407 & 1.549 & 1.660 & 1.749 \\
\hline-0.8 & 0.132 & 0.856 & 1.166 & 1.448 & 1.606 & 1.733 & 1.837 \\
\hline-0.7 & 0.116 & 0.857 & 1.183 & 1.488 & 1.663 & 1.806 & 1.926 \\
\hline-0.6 & 0.099 & 0.857 & 1.200 & 1.528 & 1.720 & 1.880 & 2.016 \\
\hline-0.5 & 0.083 & 0.856 & 1.216 & 1.567 & 1.770 & 1.955 & 2.108 \\
\hline-0.4 & 0.066 & 0.855 & 1.231 & 1.606 & 1.834 & 2.029 & 2.201 \\
\hline-0.3 & 0.500 & 0.853 & 1.245 & 1.643 & 1.890 & 2.104 & 2.294 \\
\hline-0.2 & 0.033 & 0.850 & 1.258 & 1.680 & 1.945 & 2.178 & 2.388 \\
\hline-0.1 & 0.017 & 0.846 & 1.270 & 1.716 & 2.000 & 2.252 & 2.482 \\
\hline 0.0 & 0.000 & 0.842 & 1.282 & 1.751 & 2.054 & 2.326 & 2.576 \\
\hline
\end{tabular}

\section{d. Uji Kecocokan}

Data hidrologi yang dipakai untuk mengestimasi debit menggunakan analisis frekuensi belum tentu sesuai dengan distribusi-distribusi yang dipilih. Setelah didapatkan distribusi yang memenuhi syarat sesuai dengan data statistik, selanjut dilakukan uji kecocokan, salah satunya adalah uji Smirnov Kolmogorov.

Tabel 7. Faktor Frekuensi (KTr) Log Pearson III Untuk Cs Positif

\begin{tabular}{|c|c|c|c|c|c|c|c|}
\hline \multirow{4}{*}{$\begin{array}{c}\text { Skew } \\
\text { Coef. } \\
\text { C' }^{\prime} \\
\text { Cs' }^{\prime}\end{array}$} & \multicolumn{7}{|c|}{ RETURN PERIODE(YEAR) } \\
\hline & 2 & 5 & 10 & 25 & 50 & 100 & 200 \\
\hline & \multicolumn{7}{|c|}{ EXCEEDENCE PROBABILITY } \\
\hline & 0.500 & 0.200 & 0.100 & 0.040 & 0.020 & 0.010 & 0.005 \\
\hline 0.0 & 0.000 & 0.842 & 1.282 & 1.751 & 2.054 & 2.326 & 2.576 \\
\hline 0.1 & -0.017 & 0.836 & 1.292 & 1.785 & 2.107 & 2.400 & 2.670 \\
\hline 0.2 & -0.033 & 0.830 & 1.301 & 1.818 & 2.159 & 2.472 & 2.763 \\
\hline 0.3 & -0.050 & 0.824 & 1.309 & 1.849 & 2.211 & 2.544 & 2.856 \\
\hline 0.4 & -0.066 & 0.816 & 1.317 & 1.880 & 2.261 & 2.615 & 2.949 \\
\hline 0.5 & -0.083 & 0.808 & 1.323 & 1.910 & 2.311 & 2.686 & 3.041 \\
\hline 0.6 & -0.099 & 0.800 & 1.328 & 1.939 & 2.359 & 2.755 & 3.132 \\
\hline 0.7 & -0.116 & 0.790 & 1.333 & 1.967 & 2.407 & 2.824 & 3.223 \\
\hline 0.8 & -0.132 & 0.780 & 1.336 & 1.998 & 2.453 & 2.891 & 3.312 \\
\hline 0.9 & -0.148 & 0.769 & 1.339 & 2.018 & 2.498 & 2.957 & 3.401 \\
\hline 1.0 & -0.164 & 0.758 & 1.340 & 2.043 & 2.542 & 3.022 & 3.489 \\
\hline 1.1 & -0.180 & 0.745 & 1.341 & 2.066 & 2.585 & 3.087 & 3.575 \\
\hline 1.2 & -0.195 & 0.732 & 1.340 & 2.087 & 2.626 & 3.149 & 3.661 \\
\hline 1.3 & -0.210 & 0.719 & 1.339 & 2.108 & 2.666 & 3.211 & 3.745 \\
\hline 1.4 & -0.225 & 0.705 & 1.337 & 2.128 & 2.706 & 3.271 & 3.828 \\
\hline 1.5 & -0.240 & 0.690 & 1.333 & 2.146 & 2.743 & 3.330 & 3.910 \\
\hline 1.6 & -0.254 & 0.675 & 1.329 & 2.163 & 2.780 & 3.388 & 3.990 \\
\hline 1.7 & -0.268 & 0.660 & 1.324 & 2.179 & 2.815 & 3.444 & 4.069 \\
\hline 1.8 & -0.282 & 0.643 & 1.318 & 2.193 & 2.828 & 3.499 & 4.147 \\
\hline 1.9 & -0.282 & 0.627 & 1.310 & 2.207 & 2.881 & 3.553 & 4.223 \\
\hline 2.0 & -0.307 & 0.609 & 1.302 & 2.219 & 2.912 & 3.605 & 4.298 \\
\hline 2.1 & -0.319 & 0.592 & 1.294 & 2.230 & 2.942 & 3.656 & 4.372 \\
\hline 2.2 & -0.330 & 0.574 & 1.284 & 2.240 & 2.970 & 3.705 & 4.444 \\
\hline 2.3 & -0.341 & 0.555 & 1.274 & 2.248 & 3.997 & 3.753 & 4.515 \\
\hline 2.4 & -0.351 & 0.537 & 1.262 & 2.256 & 3.023 & 3.800 & 4.584 \\
\hline 2.5 & -0.360 & 0.518 & 1.250 & 2.262 & 3.048 & 3.845 & 4.652 \\
\hline 2.6 & -0.368 & 0.799 & 1.238 & 2.267 & 3.017 & 3.899 & 4.718 \\
\hline 2.8 & -0.384 & 0.460 & 1.210 & 2.275 & 3.114 & 3.937 & 4.847 \\
\hline 2.8 & -0.376 & 0.479 & 1.224 & 2.272 & 3.093 & 3.932 & 4.783 \\
\hline 2.9 & -0.390 & 0.440 & 1.195 & 2.277 & 3.134 & 4.013 & 4.909 \\
\hline 3.0 & -0.396 & 0.420 & 1.180 & 2.278 & 3.152 & 4.051 & 4.970 \\
\hline
\end{tabular}

Sumber : C.D. Soemarto (1999)

Pengujian kecocokan distribusi dengan membandingkan kemungkinan (probability) untuk setiap variat, dari distribusi empiris dan teoritisnya, akan didapat perbedaan $(\Delta)$ tertentu $^{[4]}$
Prosedur uji kecocokan Smirnov-Kolmogorov adalah:

- Urutkan data dari terkecil ke terbesar atau sebaliknya dan tentukan besarnya nilai masingmasing data tersebut

- Hitung probabilitasnya dengan menggunakan rumus Weilbull:

$$
P=\frac{m}{n+1} \times 100 \%
$$

dengan :

$$
\begin{array}{ll}
\mathrm{P} & =\text { probabilitas }(100 \%) \\
\mathrm{m} & =\text { nomor urut data } \\
\mathrm{n} & =\text { jumlah data }
\end{array}
$$

- Dari kedua nilai peluang tersebut, tentukan selisih terbesarnya antara nilai aktual dengan nilai prediksi.

$$
\Delta_{\text {maks }}=\left[X_{\text {aktual }}-X_{\text {prediksi }}\right]
$$

dengan :

$\Delta_{\text {maks }}=$ selisih maksimum nilai aktual dan nilai prediksi

$X_{\text {aktual }}=$ nilai aktual

$X_{\text {prediksi }}=$ nilai prediksi

$\Delta_{c r} \quad=$ simpangan kritis

Kemudian bandingkan antara $\Delta_{\text {maks }}$ dan $\Delta_{c r}$, distribusi frekuensi yang dipilih dapat diterima apabila $\Delta_{\text {maks }}<\Delta_{c r}$ dan jika $\Delta_{\text {maks }}>\Delta_{c r}$ berarti ditolak. Nilai kritis untuk uji Smirnov Kolmogorov disajikan pada Tabel 8.

Tabel 8. Nilai Kritis Smirnov-Kolmogorov

\begin{tabular}{|crrrrr|}
\hline $\mathrm{n}$ & $\alpha=0,20$ & $\alpha=0,10$ & $\alpha=0,05$ & $\alpha=0,02$ & $\alpha=0,01$ \\
\hline 1 & 0,900 & 0,950 & 0,975 & 0,990 & 0,995 \\
2 & 0,684 & 0,776 & 0,842 & 0,900 & 0,929 \\
3 & 0,565 & 0,636 & 0,708 & 0,785 & 0,829 \\
4 & 0,493 & 0,565 & 0,624 & 0,689 & 0,734 \\
5 & 0,447 & 0,509 & 0,563 & 0,627 & 0,669 \\
6 & 0,410 & 0,468 & 0,519 & 0,577 & 0,617 \\
7 & 0,381 & 0,436 & 0,483 & 0,538 & 0,576 \\
8 & 0,359 & 0,410 & 0,454 & 0,507 & 0,542 \\
9 & 0,339 & 0,387 & 0,430 & 0,480 & 0,513 \\
10 & 0,323 & 0,369 & 0,409 & 0,457 & 0,486 \\
11 & 0,308 & 0,352 & 0,391 & 0,437 & 0,468 \\
12 & 0,296 & 0,338 & 0,375 & 0,419 & 0,449 \\
13 & 0,285 & 0,325 & 0,361 & 0,404 & 0,432 \\
14 & 0,275 & 0,314 & 0,349 & 0,390 & 0,418 \\
15 & 0,266 & 0,304 & 0,338 & 0,377 & 0,404 \\
16 & 0,258 & 0,295 & 0,327 & 0,366 & 0,392 \\
17 & 0,250 & 0,286 & 0,318 & 0,355 & 0,381 \\
18 & 0,244 & 0,279 & 0,309 & 0,346 & 0,371 \\
19 & 0,237 & 0,271 & 0,301 & 0,337 & 0,361 \\
20 & 0,232 & 0,265 & 0,294 & 0,329 & 0,352 \\
21 & 0,226 & 0,259 & 0,287 & 0,321 & 0,344 \\
22 & 0,221 & 0,253 & 0,281 & 0,314 & 0,337 \\
23 & 0,216 & 0,247 & 0,275 & 0,307 & 0,330 \\
24 & 0,212 & 0,242 & 0,269 & 0,301 & 0,323 \\
25 & 0,208 & 0,238 & 0,264 & 0,295 & 0,317 \\
\hline Pendekatan $1,07 / \sqrt{ } \mathrm{n}$ & $1,22 / \sqrt{ } \mathrm{n}$ & $1,36 / \sqrt{ } \mathrm{n}$ & $1,52 / \sqrt{ } \mathrm{n}$ & $1,63 / \sqrt{ } \mathrm{n}$ \\
\hline
\end{tabular}

Sumber : Lily Montarcih Limantara (2010)

\section{(1) Debit Andalan}

Debit andalan adalah besarnya debit yang tersedia untuk memenuhi kebutuhan air dengan resiko kegagalan yang telah diperhitungkan dan 
bertujuan untuk menentukan debit perencanaan yang diharapkan selalu tersedia di sungai ${ }^{[3]}$. Menurut pengamatan dan pengalaman, besarnya debit andalan untuk berbagai keperluan dapat dilihat pada Tabel 9.

Tabel 9. Debit Andalan Untuk Berbagai Keperluan

\begin{tabular}{|l|c|}
\hline \multicolumn{1}{|c|}{ Keperluan } & Debit Andalan \\
\hline Air minum & $99 \%$ (seringkali mendekati 100\%) \\
\hline Industri & $95-98 \%$ \\
\hline Irigasi : setengahlembab & $70-85 \%$ \\
\hline Kering & $80-95 \%$ \\
\hline PLTA & $85-90 \%$ \\
\hline
\end{tabular}

Sumber : Lily Montarcih Limantara (2010)

\section{a. Metode Debit Rata-Rata Minimum}

Karakteristik Metode Debit Rata-Rata Minimum antara lain :

- Dalam satu tahun hanya diambil satu data (data debit rata-rata harian dalam satu tahun)

- Metode ini cocok untuk Daerah Aliran Sungai (DAS) dengan fluktuasi debit maksimum dan debit minimum tidak terlalu besar dari tahun ke tahun, serta kebutuhan relatif konstan sepanjang tahun.

Analisa debit andalan berdasarkan metode debit rata-rata minimum menggunakan analisis frekuensi, yaitu dengan jenis distribusi Gumbel dan Log Pearson Tipe III, serta dilakukan uji kecocokan distribusi menggunakan Smirnov Kolmogorov.

\section{b. Metode Flow Characteristic}

Metode Flow Characteristic berhubungan dengan basis tahun normal, tahun kering dan tahun basah. Debit berbasis tahun normal adalah jika debit rata-rata tahunnya kurang lebih sama dengan debit rata-rata keseluruhan tahun $\left(\mathrm{Q}_{\mathrm{rt}} \approx \mathrm{Q}_{\mathrm{r}}\right)$. Untuk debit berbasis tahun kering adalah jika debit rata-rata tahunannya lebih kecil dari debit rata-rata keseluruhan tahun $\left(\mathrm{Q}_{\mathrm{rt}}<\mathrm{Q}_{\mathrm{r}}\right)$. sedangkan untuk debit berbasis tahun basah adalah jika debit rata-rata tahunannya lebih kecil dari debit rata-rata keseluruhan tahun $\left(\mathrm{Q}_{\mathrm{rt}}>\mathrm{Q}_{\mathrm{r}}\right)$. $\mathrm{Q}_{\mathrm{rt}}$ adalah debit ratarata tahunan sedangkan $Q_{r}$ adalah debit rata-rata semua tahun.

Metode ini cocok untuk:

- DAS dengan fluktuasi debit maksimum dan debit minimum relatif besar dari tahun ke tahun

- Kebutuhan relatif tidak konstan sepanjang tahun

- Data yang tersedia cukup panjang

Keandalan berdasarkan kondisi debit dibedakan menjadi 4, antara lain:

- Debit air musim kering, yaitu debit yang dilampaui oleh debit-debit sebanyak 355 hari dalam 1 tahun dengan keandalan : (355/365) x $100 \%=97,3 \%$
- Debit air rendah, yaitu debit yang dilampaui oleh debit-debit sebanyak 275 hari dalam 1 tahun dengan keandalan : $(275 / 365) \times 100 \%=75,3 \%$

- Debit air normal, yaitu debit yang dilampaui oleh debit-debit sebanyak 185 hari dalam 1 tahun dengan keandalan : $(185 / 365) \times 100 \%=50,7 \%$ Debit air cukup, yaitu debit yang melampaui oleh debit-debit sebanyak 95 hari dalam 1 tahun dengan keandalan : $(95 / 365) \times 100 \%=26,0 \%$

c. Metode Tahun Dasar Perencanaan

Analisis debit andalan dengan metode ini biasanya diguakan dalam perencanaan atau pengelolaan irigasi. Umumnya di bidang irigasi dipakai debit dengan keandalan $80 \%$ sehingga rumus untuk menentukan tahun dasar perencanaan adalah sebagai berikut :

$$
R_{80}=\frac{n}{5}+1
$$

dengan :

$\mathrm{n} \quad=$ kala ulang pengamatan yang diinginkan

$\mathrm{R}_{80}=$ debit yang terjadi $<\mathrm{R}_{80}$ adalah $20 \%$ dan $\geq \mathrm{R}_{80}$

\section{d. Metode Bulan Dasar Perencanaan}

Analisis debit andalan menggunakan Metode Bulan Dasar Perencanaan hampir sama dengan Metode Flow Characteristic yang dianalisis untuk bulan-bulan tertentu. Metode ini paling sering dipakai karena keandalan debit dihitung mulai Bulan Januari sampai dengan Bulan Desember, jadi lebih bisa menggambarkan keandalan pada musim kemarau dan musim penghujan.

\section{Metodologi Penelitian}

\section{(1) Studi Literatur}

Studi literatur yaitu mengumpulkan dan mempelajari bahan-bahan yang berhubungan dengan masalah-masalah yang diteliti. Bahan-bahan tersebut berupa bahan yang didapat dari tulisan-tulisan ilmiah, diktat-diktat, buku-buku maupun internet yang berkaitan dengan masalah yang diteliti.

\section{(2) Pengumpulan Data}

Data yang diperoleh dalam penelitian ini adalah data sekunder, yaitu data debit Sungai Komering, peta DAS Musi, dan peta Sub DAS Komering. Datadata tersebut diperoleh dari Dinas Pekerjaan Umum Sumatera Selatan dan Balai Besar Wilayah Sungai (BBWS) Sumatera VIII. Dengan penjabaran pendataan data sebagai berikut :

a. Data debit harian Sungai Komering selama sebelas tahun dari tahun 2000 hingga tahun 2010. Data debit sungai yang digunakan adalah data debit harian di titik tinjau pintu dan saluran Bendung Perjaya.

b. Peta DAS Musi, Sub DAS Komering, dan peta lokasi Bendung Perjaya. Peta-peta ini diperoleh dari Balai Besar Wilayah Sungai (BBWS) Sumatera VIII. 
(3) Pengolahan Data

Secara garis besar, tahapan-tahapan pada penelitian ini dapat diuraikan sebagai berikut :

a. Tahap indentifikasi

Tahapan indentifikasi digunakan untuk mengetahui pola dalam data debit Sungai Komering yang akan dianalisis. Cara yang digunakan untuk mengetahui pola data adalah :

- Mengubah data debit harian menjadi data bulanan dan tahunan

- Menentukan debit maksimum, debit rata-rata dan debit minimum

- $\quad$ Plot time series data debit

b. Tahap analisa debit banjir

Analisa debit banjir dilakukan pada data debit maksimum tahunan Sungai Komering. Cara yang digunakan untuk menganalisa debit banjir ini adalah

- Menentukan tipe distribusi dengan histogram, yaitu dengan melihat bentuk kurva frekuensi yang dihasilkan dari data debit maksimum tersebut.

- Menentukan tipe distribusi dengan parameterparameter statistik berupa nilai rata-rata, standar deviasi, koefisien kurtosis, dan koefisien variasi.

- Menentukan tipe distribusi dengan analisis frekuensi dengan empat tipe distribusi, yaitu distribusi Normal, distribusi Log Normal, distribusi Gumbel, dan distribusi Log Pearson III.

- Melakukan uji kecocokan Smirnov Kolmogorov untuk menentukan persamaan distribusi yang dapat mewakili dari distribusi statistik sampel data debit yang dianalisis.

- Melakukan analisis kala ulang debit banjir, apakah debit banjir tersebut akan melampaui atau menyamai suatu harga tertentu dengan kala ulang $2,5,10,25,50$, dan 100 tahun.

c. Tahap analisa debit andalan

Pada penelitian ini, metode yang digunakan untuk analisa debit andalan adalah metode Bulan Dasar Perencanaan.

Tahapannya, yaitu :

- Menentukan debit rata-rata dengan cara terlebih dahulu menentukan debit rata-rata 15 harian atau dua periode pada setiap bulannya dalam kurun waktu sebelas tahun yaitu tahun 20002010.

- Melakukan analisis debit andalan $80 \%$ pada masing-masing periode tiap bulan dan dalam kurun waktu tersebut dengan berdasarkan distribusi Gumbel

- Melakukan analisis debit andalan 80\% pada masing-masing periode tiap bulan dan dalam kurun waktu tersebut dengan berdasarkan metode Log Pearson III.

- Melakukan uji kecocokan dengan uji Smirnov Kolmogorov. Untuk bulan-bulan yang lain dapat dilakukan dengan analisis yang sama. d. Tahap Pembahasan

Pada tahap ini diakukan pembahasan mengenai data, debit banjir, dan debit andalan yang telah dianalisis sebelumnya

\section{IV.Analisis Dan Pembahasan}

\section{(1) Identifikasi Data}

Data-data yang digunakan pada penelitian ini berupa data peta DAS Musi dan data debit Sungai Komering berupa data debit harian yang terukur pada pintu dan saluran Bendung Perjaya. Kemudian data harian tersebut direkapitulasi agar dapat dijadikan suatu plot time series. Hasil rekapitulasi data hujan dapat dilihat pada Tabel 10 dan plot time series data dapat dilihat pada Gambar 2.

Tabel 10. Daftar Debit Sungai Komering

\begin{tabular}{|c|c|c|c|c|}
\hline \multirow{2}{*}{ No } & \multirow{2}{*}{ Tahun } & \multicolumn{3}{|c|}{$\begin{array}{c}\text { JUMLAH DEBIT } \\
\text { KESELURUHAN } \\
\left(\mathrm{m}^{3} / \text { det }\right)\end{array}$} \\
\cline { 3 - 5 } & & Maksimum & Minimum & Rata-Rata \\
\hline 1 & 2000 & 694,60 & 17,22 & 181,97 \\
2 & 2001 & 975,58 & 22,25 & 217,93 \\
3 & 2002 & 976,81 & 50,20 & 170,79 \\
4 & 2003 & 1970,00 & 58,60 & 314,20 \\
5 & 2004 & 1400,00 & 33,36 & 216,44 \\
6 & 2005 & 888,99 & 33,36 & 297,75 \\
7 & 2006 & 780,36 & 45,08 & 181,96 \\
8 & 2007 & 762,87 & 43,50 & 194,71 \\
9 & 2008 & 1240,75 & 38,39 & 199,95 \\
10 & 2009 & 705,36 & 8,50 & 180,75 \\
11 & 2010 & 1272,07 & 21,45 & 283,36 \\
\hline
\end{tabular}

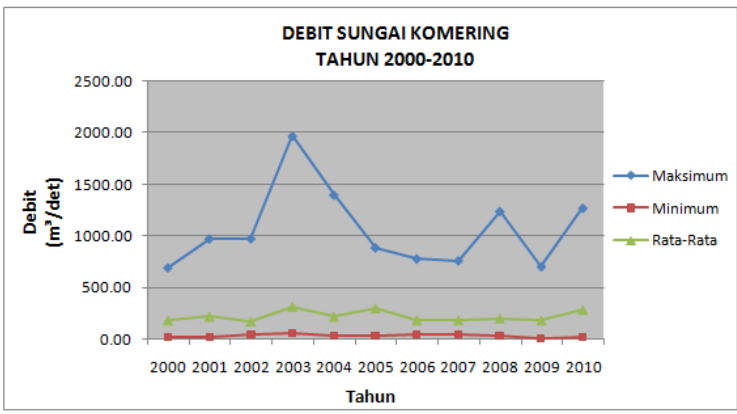

Gambar 2. Plot Time Series Sungai Komering 2000-2010 Sumber : Hasil Perhitungan (2012)

Tahun 2000 Sungai Komering memiliki debit maksimum sebesar $694,60 \mathrm{~m}^{3} / \mathrm{dt}$, debit minimum sebesar $17,22 \mathrm{~m}^{3} / \mathrm{dt}$ dan debit rata-rata sebesar $181,97 \mathrm{~m}^{3} / \mathrm{dt}$, tahun 2001 debit maksimum sebesar $975,58 \mathrm{~m}^{3} / \mathrm{dt}$, debit minimum sebesar $22.55 \mathrm{~m}^{3} / \mathrm{dt}$, dan debit rata-rata sebesar $217,93 \mathrm{~m}^{3} / \mathrm{dt}$, tahun 2002 debit maksimum sebesar 976,81 $\mathrm{m}^{3} / \mathrm{dt}$ debit minimum sebesar $58,60 \mathrm{~m}^{3} / \mathrm{dt}$, dan debit rata-rata sebesar $170,93 \mathrm{~m}^{3} / \mathrm{dt}$ dan seterusnya untuk tahun 2003 hingga tahun 2010

\section{(2) Analisa Debit Banjir}

Dalam menganalisa debit banjir data debit yang digunakan yaitu data debit maksimum Sungai Komering dari tahun 2000 hingga tahun 2010. 
a. Penentuan Tipe Distribusi dengan Cara Histogram

Tabel 11. Penentuan Distribusi Dengan Histogram

\begin{tabular}{|c|c|c|c|c|}
\hline Kelas & Debit & Rentang Debit & $\begin{array}{c}\text { Nilai Kelas } \\
\text { (xi) }\end{array}$ & $\begin{array}{c}\text { Frekuensi } \\
\text { (fi) }\end{array}$ \\
\hline 1 & $694,60<\mathrm{Q}<949,68$ & $695,10-949,18$ & 822,14 & 5 \\
2 & $949,67<\mathrm{Q}<1.204,76$ & $950,17-1.204,26$ & $1.077,22$ & 2 \\
3 & $1.204,77<\mathrm{Q}<1.459,84$ & $1.205,27-1.459,34$ & $1.332,31$ & 3 \\
4 & $1.459,85<\mathrm{Q}<1.714,92$ & $1.460,35-1.714,42$ & $1.587,39$ & 0 \\
5 & $1.714,93<\mathrm{Q}<1.970,00$ & $1.715,43-1.969,50$ & $1.842,47$ & 1 \\
\hline
\end{tabular}

Sumber : Hasil perhitungan (2012)

Dari histogram tersebut dapat dilihat bahwa kurva frekuensi berbentuk asimetris, nilai variabel di samping kiri dan kanan yang berjarak tidak sama terhadap titik tengah sehingga bukan distribusi normal.

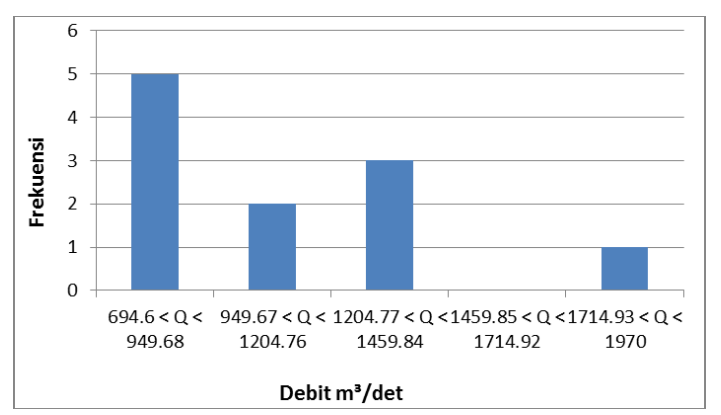

Gambar 3. Histogram Debit Maksimum Sumber : Hasil perhitungan (2012)

b. Penentuan Tipe Distribusi dengan Parameter Statistik

Tabel 12. Parameter Statistik Debit Banjir SungaiKomering

\begin{tabular}{|c|c|}
\hline Parameter & Nilai \\
\hline Nilai Rata-Rata (X) & $1.060,67 \mathrm{~m}^{3} / \mathrm{dt}$ \\
\hline Standar Deviasi (S) & $386,06 \mathrm{~m}^{3} / \mathrm{dt}$ \\
\hline Koefisien Skewness (Cs) & 1,40 \\
\hline Koefisien Kurtosis (Ck) & 2,01 \\
\hline Koefisien Variasi (Cv) & 0,36 \\
Sumber : Hasil Perhitungan $(2012)$
\end{tabular}

Nilai-nilai parameter statistik pada tabel di atas kemudian dibandingkan dengan syarat-syarat statistik yang terdapat pada Tabel 2.1. Dapat dilihat bahwa tipe distribusi yang dapat digunakan yaitu distribusi Gumbel karena memenuhi salah satu persyaratan, yaitu $\mathrm{Cs}=1,40$.

c. Penentuan Tipe Distribusi dengan Analisis Frekuensi

Hasil analisis frekuensi berdasarkan masing-masing jenis ditribusi disajikan pada Tabel 13 sampai dengan Tabel 20.
Tabel 13. Perhitungan Distribusi Normal

\begin{tabular}{|c|c|r|c|c|}
\hline No. & Tahun & $\begin{array}{c}\mathbf{Q} \\
\left(\mathbf{m}^{\mathbf{3}} / \mathbf{d t}\right)\end{array}$ & No. Urut & $\begin{array}{c}\mathbf{Q} \text { urut } \\
\left(\mathbf{m}^{3} / \mathbf{d t} \mathbf{)}\right.\end{array}$ \\
\hline 1 & 2000 & 694,60 & 11 & $1.970,00$ \\
2 & 2001 & 975,58 & 6 & $1.400,00$ \\
3 & 2002 & 976,81 & 5 & $1.272,07$ \\
4 & 2003 & $1.970,00$ & 1 & $1.240,75$ \\
5 & 2004 & $1.400,00$ & 2 & 976,81 \\
6 & 2005 & 888,99 & 7 & 975,58 \\
7 & 2006 & 780,36 & 8 & 888,99 \\
8 & 2007 & 762,87 & 9 & 780,36 \\
9 & 2008 & $1.240,75$ & 4 & 762,87 \\
10 & 2009 & 705,36 & 10 & 705,36 \\
11 & 2010 & $1.272,07$ & 3 & 694,60 \\
\hline \multicolumn{5}{|c|}{$\Sigma$} \\
\hline
\end{tabular}

Sumber : Hasil Perhitungan (2012)

Tabel 14. Periode Ulang Debit Banjir Distribusi Normal

\begin{tabular}{|c|c|c|}
\hline $\begin{array}{c}\text { Tr } \\
\text { (tahun) }\end{array}$ & KTr & $\begin{array}{c}\text { Debit Banjir } \\
\left(\mathbf{m}^{3} / \mathbf{d t}\right)\end{array}$ \\
\hline 2 & 0,00 & $1.060,67$ \\
\hline 5 & 0,84 & $1.384,96$ \\
\hline 10 & 1,28 & $1.554,83$ \\
\hline 25 & 1,64 & $1.693,81$ \\
\hline 50 & 2,05 & $1.852,09$ \\
\hline 100 & 2,33 & $1.960,19$ \\
\hline
\end{tabular}

Sumber : Hasil Perhitungan (2012)

Tabel 15. Perhitungan Distribusi Log Normal

\begin{tabular}{|c|c|c|c|c|c|c|c|}
\hline No. & Tahun & $\underset{\left(\mathrm{m}^{3} / \mathrm{dt}\right)}{\mathbf{Q}}$ & $\begin{array}{l}\text { No. } \\
\text { Urut }\end{array}$ & 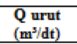 & $\begin{array}{l}\begin{array}{l}\log Q \\
\left(\mathrm{~m}^{2} / \mathrm{dt}\right)\end{array} \\
\end{array}$ & $\begin{array}{c}(\log Q-\log Q t)^{2} \\
\left(\mathrm{~m}^{2} / \mathrm{dt}\right)\end{array}$ & $\begin{array}{c}(\log Q-\log Q t)^{3} \\
\left(\mathrm{~m}^{3} / \mathrm{dt}\right)\end{array}$ \\
\hline 1 & 2000 & 694,60 & 11 & $1.970,00$ & 2,84 & 0,025967 & $-0,004184$ \\
\hline 2 & 2001 & 975,58 & 6 & $1.400,00$ & 2,99 & 0,000185 & $-0,000003$ \\
\hline 3 & 2002 & 976,81 & 5 & $1.272,07$ & 2,99 & 0,000171 & $-0,000002$ \\
\hline 4 & 2003 & $1.970,00$ & 1 & $1.240,75$ & 3,29 & 0,085024 & 0,024792 \\
\hline 5 & 2004 & $1.400,00$ & 2 & 976,81 & 3,15 & 0,020521 & 0,002940 \\
\hline 6 & 2005 & 888,99 & 7 & 975,58 & 2,95 & 0,002914 & $-0,000157$ \\
\hline 7 & 2006 & 780,36 & 8 & 888,99 & 2,89 & 0,012228 & $-0,001352$ \\
\hline 8 & 2007 & 762,87 & 9 & 780,36 & 2,88 & 0,014503 & $-0,001747$ \\
\hline 9 & 2008 & $1.240,75$ & 4 & 762,87 & 3,09 & 0,008246 & 0,000749 \\
\hline 10 & 2009 & 705,36 & 10 & 705,36 & 2,85 & 0,023860 & $-0,003686$ \\
\hline 11 & 2010 & $1.272,07$ & 3 & 694,60 & 3,10 & 0,010329 & 0,001050 \\
\hline \multicolumn{4}{|c|}{$\bar{\Sigma}$} & $11.667,39$ & 33,03 & 0,203948 & 0,018400 \\
\hline
\end{tabular}

Sumber : Hasil Perhitungan (2012)

Tabel 16. Periode Ulang Debit Banjir Distribusi Log Normal

\begin{tabular}{|c|c|c|}
\hline $\begin{array}{c}\text { Tr } \\
\text { (tahun) }\end{array}$ & KTr & $\begin{array}{c}\text { Debit Banjir } \\
\left(\mathbf{m}^{3} / \mathbf{d t}\right)\end{array}$ \\
\hline 2 & $-0,0250$ & $1.000,00$ \\
\hline 5 & 0,8334 & $1.324,02$ \\
\hline 10 & 1,2965 & $1.548,82$ \\
\hline 25 & 1,7609 & $1.796,21$ \\
\hline 50 & 2,1341 & $2.030,71$ \\
\hline 100 & 2,4570 & $2.258,72$ \\
\hline
\end{tabular}

Sumber : Hasil Perhitungan (2012)

Tabel 17. Perhitungan Dengan Distribusi Gumbel

\begin{tabular}{|c|c|c|c|c|c|}
\hline No. & Tahun & $\begin{array}{c}\mathbf{Q} \\
\left(\mathrm{m}^{2} / \mathrm{dt}\right)\end{array}$ & No. Urut & $\begin{array}{l}\text { Q urut } \\
\left(\mathrm{m}^{3} / \mathrm{dt}\right)\end{array}$ & $\begin{array}{c}\left(Q^{\prime}-Q\right)^{2} \\
\left(\mathrm{~m}^{5} / \mathrm{dt}\right)\end{array}$ \\
\hline 1 & 2000 & 694,60 & 11 & $1.970,00$ & 826877,74 \\
\hline 2 & 2001 & 975,58 & 6 & $1.400,00$ & 115143,61 \\
\hline 3 & 2002 & 976,81 & 5 & $1.272,07$ & 44689,19 \\
\hline 4 & 2003 & $1.970,00$ & 1 & $1.240,75$ & 32428,15 \\
\hline 5 & 2004 & $1.400,00$ & 2 & 976,81 & 7032,80 \\
\hline 6 & 2005 & 888,99 & 7 & 975,58 & 7240,62 \\
\hline 7 & 2006 & 780,36 & 8 & 888,99 & 29474,65 \\
\hline 8 & 2007 & 762,87 & 9 & 780,36 & 78574,72 \\
\hline 9 & 2008 & $1.240,75$ & 4 & 762,87 & 88685,92 \\
\hline 10 & 2009 & 705,36 & 10 & 705,36 & 126246,49 \\
\hline 11 & 2010 & $1.272,07$ & 3 & 694,60 & 134008,58 \\
\hline & & & & 11.667 .39 & 1.490 .402 .47 \\
\hline
\end{tabular}


Tabel 18. Periode Ulang Debit Banjir Distribusi Gumbel

\begin{tabular}{|c|c|c|}
\hline $\begin{array}{c}\text { Tr } \\
\text { (tahun) }\end{array}$ & Yt & $\begin{array}{c}\text { Debit Banjir } \\
\left(\mathbf{m}^{3} / \mathbf{d t}\right)\end{array}$ \\
\hline 2 & 0,37 & $1.007,57$ \\
\hline 5 & 1,50 & $1.459,79$ \\
\hline 10 & 2,25 & $1.759,20$ \\
\hline 25 & 3,20 & $2.137,50$ \\
\hline 50 & 3,90 & $2,418,15$ \\
\hline 100 & 4,60 & $2,696,73$ \\
\hline
\end{tabular}

Sumber : Hasil Perhitungan (2012)

Tabel 19. Perhitungan Dengan Distribusi Log Pearson III

\begin{tabular}{|c|c|c|c|c|c|c|c|}
\hline No. & Tahun & $\underset{\left(\mathrm{m}^{2} / \mathrm{dt}\right)}{Q}$ & $\begin{array}{l}\text { No. } \\
\text { Urut }\end{array}$ & $\begin{array}{l}Q \text { Q urut } \\
\left(\mathrm{m}^{5} / \mathrm{dt}\right)\end{array}$ & $\begin{array}{l}\begin{array}{l}\text { Log } Q \\
\left(\mathrm{~m}^{2} / \mathrm{dt}\right)\end{array} \\
\end{array}$ & $\begin{array}{c}(\log \mathbf{Q}-\log \mathbf{Q} t)^{2} \\
\left(\mathrm{~m}^{3} / \mathrm{dt}\right)^{2}\end{array}$ & $\frac{(\log Q-\log Q t)^{3}}{\left(\mathrm{~m}^{\prime} / \mathrm{d} t\right)^{3}}$ \\
\hline 1 & 2000 & & 11 & & 2,84 & & \\
\hline 2 & 2001 & 975,58 & 6 & $1.400,00$ & 2,99 & 0,000185 & $-0,000003$ \\
\hline 3 & 2002 & 976,81 & 5 & $1.272,07$ & 2,99 & 0,000171 & $-0,000002$ \\
\hline 4 & 2003 & $1.970,00$ & 1 & $1.240,75$ & 3,29 & 0,085024 & 0,024792 \\
\hline 5 & 2004 & $1.400,00$ & 2 & 976,81 & 3,15 & 0,020521 & 0,002940 \\
\hline 6 & 2005 & 888,99 & 7 & 975,58 & 2,95 & 0,002914 & $-0,000157$ \\
\hline 7 & 2006 & 780,36 & 8 & 888,99 & 2,89 & 0,012228 & $-0,001352$ \\
\hline 8 & 2007 & 762,87 & 9 & 780,36 & 2,88 & 0,014503 & $-0,001747$ \\
\hline 9 & 2008 & $1.240,75$ & 4 & 762,87 & 3,09 & 0,008246 & 0,000749 \\
\hline 10 & 2009 & 705,36 & 10 & 705,36 & 2,85 & 0,023860 & $-0,003686$ \\
\hline 11 & 2010 & $1.272,07$ & 3 & 694,60 & 3,10 & 0,010329 & 0,001050 \\
\hline \multicolumn{4}{|c|}{$\bar{\Sigma}$} & $11.667,39$ & 33,03 & 0,203948 & 0,018400 \\
\hline
\end{tabular}

Sumber : Hasil perhitungan (2012)

Tabel 20. Periode Ulang Debit Banjir Distribusi Log Pearson III

\begin{tabular}{|c|c|c|}
\hline $\begin{array}{c}\text { Tr } \\
\text { (tahun) }\end{array}$ & KTr & $\begin{array}{c}\text { Debit Banjir } \\
\left(\mathbf{m}^{3} / \mathbf{d t}\right)\end{array}$ \\
\hline 2 & $-0,127$ & 965,47 \\
\hline 5 & 0,783 & $1.302,17$ \\
\hline 10 & 1,335 & $1.561,54$ \\
\hline 25 & 1,989 & $1.936,10$ \\
\hline 50 & 2,439 & $2.244,87$ \\
\hline 100 & 2,871 & $2.587,53$ \\
\hline
\end{tabular}

Sumber : Hasil perhitungan (2012)

c. Uji Kecocokan Smirnov Kolmogorov

Untuk mengetahui tipe distribusi yang dapat dipakai pada analisis debit banjir Sungai Komering, dilakukanlah suat uji kecocokan. Uji kecocokan yang digunakan pada analisis debit banjir ini adalah adalah Smirnov Kolmogorov. Berdasarkan Tabel 8, nilai kritis $\left(\Delta_{c r}\right)$ Smirnov Kolmogorov untuk 11 sampel adalah 0,391. Dari hasil uji kecocokan, distribusi yang dapat digunakan adalah distribusi yang memiliki nilai selisih maksimal uji kecocokannya terkecil yaitu distribusi Gumbel. hasil uji kecocokan Smirnov Kolmogorov dapat dilihat pada Tabel 21.

Tabel 21. Rekapitulasi Uji Smirnov Kolmogorov

\begin{tabular}{|c|r|r|r|c|}
\hline \multirow{2}{*}{ No. } & \multicolumn{4}{|c|}{ Selisih Untuk Nilai Kritis 5\% } \\
\cline { 2 - 5 } & Normal & Log Normal & Gumbell & Log Pearson III \\
\hline 1 & 438,41 & 437,73 & 158,93 & 391,45 \\
2 & 21,85 & 78,98 & 114,54 & 71,05 \\
3 & 16,32 & 89,22 & 69,01 & 70,41 \\
4 & 16,05 & 147,07 & 22,74 & 12194 \\
5 & 198,49 & $-52,35$ & 145,74 & 81,69 \\
6 & 159,36 & $-3,71$ & 68,97 & 36,07 \\
7 & 211,82 & $-50,02$ & 89,62 & 84,67 \\
8 & 290,89 & $-125,10$ & 141,12 & 161,54 \\
9 & 282,31 & $-113,99$ & 108,22 & 151,88 \\
10 & 316,49 & $-146,69$ & 120,66 & 185,77 \\
11 & 306,15 & $-135,61$ & 90,65 & 175,69 \\
\hline Selisih Maks & 438,41 & 437,73 & 158,93 & 391,45 \\
Uii Kecocokan & Ditolak & Ditolak & Ditolak & Ditolak \\
\hline
\end{tabular}

Sumber : Hasil Perhitungan (2012) d. Analisis Kala Ulang Debit Banjir

Berdasarkan distribusi terpilih dilakukan analisis debit banjir dengan kala ulang 2, 5, 10, 25, 50, dan 100 tahun yang dapat dilihat pada Tabel 22 .

Tabel 22. Rekapitulasi Analisa Debit Banjir Sungai Komering

\begin{tabular}{|c|c|c|c|}
\hline $\begin{array}{c}\text { Tr } \\
\text { (tahun) }\end{array}$ & Peluang & $\mathbf{Y}_{\text {Tr }}$ & $\begin{array}{c}\text { Debit Banjir (Xt) } \\
\left(\mathrm{m}^{\mathbf{3}} / \mathrm{dt}\right)\end{array}$ \\
\hline 2 & 0,50 & 0,37 & $1.007,57$ \\
5 & 0,20 & 1,50 & $1.459,79$ \\
10 & 0,10 & 2,25 & $1.759,20$ \\
25 & 0,04 & 3,20 & $2.137,50$ \\
50 & 0,02 & 3,90 & $2.418,15$ \\
100 & 0,01 & 4,60 & $2.696,73$ \\
\hline
\end{tabular}

Sumber : Hasil Perhitungan (2012)

\section{(3) Analisa Debit Andalan}

Pada penelitian ini analisis debit andalan menggunakan metode Bulan Dasar Perencanaan dengan debit andalan untuk irigasi sebesar $80 \%$. Penggunaan metode ini karena keandalan debit dapat dihitung mulai dari bulan Januari hingga Desember sehingga lebih bisa menggambarkan keandalan. Data yang digunakan pada perhitungan dengan metode ini merupakan data debit rata-rata 15 harian atau per setengah bulanan. Data debit tersebut dapat dilihat pada Lampiran II. Dalam menganalisis debit andalan ini dilakukan dengan menggunakan dua cara, yaitu menggunakan metode Gumbel dan metode Log Pearson III.

\section{a. Distribusi Gumbel}

Contoh perhitungan :

Yn $=0,4996$

$\mathrm{Sn}=0,9676$

$\bar{X}=288,02 \mathrm{~m}^{3} / \mathrm{dt}$

$\mathrm{S}=\left[\frac{\sum_{i=1}^{n}\left(X_{i}-\bar{X}\right)^{2}}{n-1}\right]^{\frac{1}{2}}=67,03$

Cs $=\frac{n \sum_{i=1}^{n}\left(X_{i}-\bar{X}\right)^{3}}{(n-1)(n-2) S^{3}}=-0,49$

Tabel 23. Perhitungan Debit Andalan Periode I Bulan April Dengan Distribusi Gumbel

\begin{tabular}{|c|c|c|c|c|c|}
\hline $\mathrm{m}$ & Tahun & Debit (Q) & $(Q-\bar{X})^{2}$ & $(\mathbf{Q}-\bar{X})^{3}$ & $p=(m /(n+1)) \times 100 \%$ \\
\hline 1 & 2006 & 171,10 & $13.669,99$ & $-1.598 .277,69$ & 8,33 \\
\hline 2 & 2000 & 196,01 & $8.465,24$ & $-778.858,83$ & 16,67 \\
\hline 3 & 2004 & 232,78 & $3.051,10$ & $-168.532,56$ & 25,00 \\
\hline 4 & 2003 & 259,40 & 818,73 & $-23.426,54$ & 33,33 \\
\hline 5 & 2007 & 285,06 & 8,77 & $-25,97$ & 41,67 \\
\hline 6 & 2008 & 294,03 & 36,21 & 217,87 & 50,00 \\
\hline 7 & 2002 & 323,75 & $1.276,72$ & $45.618,97$ & 58,33 \\
\hline 8 & 2001 & 332,73 & $1.999,69$ & $89.422,20$ & 66,67 \\
\hline 9 & 2009 & 332,84 & $2.009,19$ & $90.059,61$ & 75,00 \\
\hline 10 & 2010 & 364,06 & $5.782,68$ & $439.737,82$ & 83,33 \\
\hline 11 & 2005 & 376,42 & $7.815,02$ & $690.868,20$ & 91,67 \\
\hline & 2 & $3.168,18$ & $44.933,33$ & $-1.213 .196,92$ & \\
\hline
\end{tabular}

Sumber : Hasil Perhitungan (2012)

Debit andalan $80 \%$, maka peluang

$$
\begin{aligned}
& \operatorname{Tr}=\frac{1}{0,8}=1,25 \\
& Y_{T}=-\ln \left[\ln \left(\frac{T r}{T r-1}\right)\right]=-0,48
\end{aligned}
$$


Maka debit andalan untuk periode I bulan April adalah :

$$
\begin{aligned}
X t= & \bar{X}+\frac{(Y t-Y n)}{S_{n}} S x \\
= & 288,02 \mathrm{~m}^{3} / \mathrm{dt}+\frac{(-0,48-0,4996)}{0,9676}+ \\
& 67,03 \mathrm{~m}^{3} / \mathrm{dt} \\
= & 220,44 \mathrm{~m}^{3} / \mathrm{dt}
\end{aligned}
$$

Debit andalan bisa dicek pada tabel. Peluang keandalan $80 \%$ berarti terjadi pada probabilitas $20 \%$, yaitu antara debit $171,10 \mathrm{~m}^{3} / \mathrm{dt}$ dan $232,78 \mathrm{~m}^{3} / \mathrm{dt}$.

Tabel 24. Rekapitulasi Debit Andalan Dengan Distribusi Gumbel

\begin{tabular}{|c|c|c|}
\hline \multirow{2}{*}{ Bulan } & Periode & $\begin{array}{c}\text { Debit Andalan } \mathbf{8 0} \% \\
\text { (m3/dt) }\end{array}$ \\
\hline \multirow{2}{*}{ Januari } & I & 129,74 \\
\cline { 2 - 3 } & II & 175,34 \\
\hline \multirow{2}{*}{ Februari } & I & 158,02 \\
\cline { 2 - 3 } Maret & II & 192,55 \\
\cline { 2 - 3 } & I & 142,63 \\
\hline \multirow{2}{*}{ April } & II & 110,50 \\
\cline { 2 - 3 } & I & 220,44 \\
\hline \multirow{2}{*}{ Mei } & II & 218,77 \\
\cline { 2 - 3 } & I & 154,23 \\
\hline \multirow{2}{*}{ Juni } & II & 156,65 \\
\cline { 2 - 3 } & II & 126,63 \\
\hline \multirow{2}{*}{ Juli } & I & 127,98 \\
\cline { 2 - 3 } Agustus & II & 68,16 \\
\cline { 2 - 3 } & I & 98,09 \\
\hline \multirow{2}{*}{ September } & II & 15,69 \\
\cline { 2 - 3 } & I & 70,96 \\
\hline \multirow{2}{*}{ Oktober } & II & 23,92 \\
\cline { 2 - 3 } & I & 49,79 \\
\hline \multirow{2}{*}{ November } & II & 70,85 \\
\cline { 2 - 3 } & II & $-86,69$ \\
\hline \multirow{2}{*}{ Desember } & I & 104,45 \\
\cline { 2 - 3 } & II & 91,45 \\
\hline \multirow{2}{*}{ Sumber $:$ Hasil Perhitungan $(2012)$} & 10,66 \\
\hline & \multicolumn{2}{|c|}{209,21} \\
\hline
\end{tabular}

\section{b. Distribusi Log Pearson III}

Contoh Perhitungan :

\begin{tabular}{|c|c|c|c|c|c|c|}
\hline $\mathrm{m}$ & Tahun & Debit Q & $\log Q$ & $(Q-\overline{\log Q})^{2}$ & $(Q-\overline{\log Q})^{3}$ & $\mathrm{p}=(\mathrm{m} /(\mathrm{n}+1)) \times 100 \%$ \\
\hline 1 & 2006 & 171,10 & 2,23 & 0,0459 & $-0,0098$ & 8,33 \\
\hline 2 & 2000 & 196,01 & 2,29 & 0,0241 & $-0,0037$ & 16,67 \\
\hline 3 & 2004 & 232,78 & 2,37 & 0,0065 & $-0,0005$ & 25,00 \\
\hline 4 & 2003 & 259,40 & 2,41 & 0,0011 & 0,0000 & 33,33 \\
\hline 5 & 2007 & 285,06 & 2,45 & 0,0001 & 0,0000 & 41,67 \\
\hline 6 & 2008 & 294,03 & 2,47 & 0,0004 & 0,0000 & 50,00 \\
\hline 7 & 2002 & 323,75 & 2,51 & 0,0039 & 0,0002 & 58,33 \\
\hline 8 & 2001 & 332,73 & 2,52 & 0,0056 & 0,0004 & 66,67 \\
\hline 9 & 2009 & 332,84 & 2,52 & 0,0056 & 0,0004 & 75,00 \\
\hline 10 & 2010 & 364,06 & 2,56 & 0,0129 & 0,0015 & 83,33 \\
\hline 11 & 2005 & 376,42 & 2,58 & 0,0165 & 0,0021 & 91,67 \\
\hline \multicolumn{3}{|c|}{2} & 26,92 & 0,1225 & $-0,0115$ & \\
\hline
\end{tabular}

$\overline{\log Q}=2,45 \mathrm{~m}^{3} / \mathrm{dt}$

Tabel 25. Perhitungan Debit Andalan Periode I Bulan April Dengan Distribusi Log Pearson III

Sumber : Hasil Perhitungan (2012)

$\mathrm{S}=\left[\frac{\sum_{i=1}^{n}\left(Q_{i}-\overline{\log Q}\right)^{2}}{n-1}\right]^{\frac{1}{2}}=0,11$

Cs $=\frac{n \sum_{i=1}^{n}\left(Q_{i}-\overline{\log Q}\right)^{3}}{(n-1)(n-2) S^{3}}=-0,85$

Untuk debit andalan $80 \%$ pada Tabel Faktor Sifat Distribusi Log Pearson III didapat $\mathrm{K}=-0,775$ sehingga :

$$
\begin{aligned}
\log X & =\overline{\log X}+(K \times S) \\
& =2,45+(-0,775 \times 0,11) \\
& =2,349 \\
X & =223,23 \mathrm{~m}^{3} / \mathrm{dt}
\end{aligned}
$$

Maka debit andalan untuk bulan April periode I adalah $223,23 \mathrm{~m}^{3} / \mathrm{dt}$. Debit andalan bisa dicek pada Tabel 4.25 , yang mana peluang sudah diranking dari kecil ke besar dan masing-masing sudah dihitung peluangnya. Peluang keandalan $80 \%$ berarti terjadi pada probabilitas $20 \%$, yaitu antara debit 171,10 $\mathrm{m}^{3} / \mathrm{dt}$ dan 232,78 $\mathrm{m}^{3} / \mathrm{dt}$. Perhitungan yang sama dilakukan pada bulan dan periode lainnya.

Tabel 26. Rekapitulasi Debit Andalan Dengan Distribusi Log Pearson III

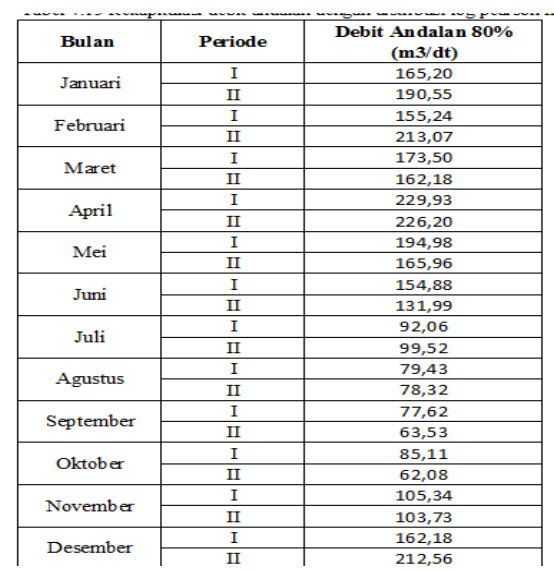

Sumber : Hasil Perhitungan (2012)

Berdasarkan Tabel 27 dapat dilihat bahwa analisa

\begin{tabular}{|c|c|c|c|c|c|c|c|}
\hline Bulan & Periode & $\begin{array}{r}\text { Peluang } 1 \\
80\end{array}$ & $\begin{array}{l}\text { Keandalan } \\
\text { o\% }\end{array}$ & Gumbel & Peluang & $\begin{array}{c}\text { Log } \\
\text { Pearson }\end{array}$ & Peluang \\
\hline \multirow{2}{*}{ Januari } & I & 126,41 & 169,81 & 129,74 & memenuhi & 165,20 & memenuhi \\
\hline & II & 100,31 & - 232,64 & 175,34 & memenuhi & 190,55 & memenuhi \\
\hline \multirow{2}{*}{ Februari } & I & 66,56 & $\begin{array}{l}-204,86 \\
\end{array}$ & 158,02 & memenuhi & 155,24 & memenuhi \\
\hline & II & 142,49 & 204,86 & 192,55 & memenuhi & 213,07 & tidak memenuhi \\
\hline \multirow{2}{*}{ Maret } & I & 121,68 & $\begin{array}{l}-206,89 \\
\end{array}$ & 142,63 & memenuhi & 173,50 & memenuhi \\
\hline & II & 145,72 & $\begin{array}{l}0179,90 \\
\end{array}$ & 110,50 & tidak memenuhi & 162,18 & memenuhi \\
\hline \multirow{2}{*}{ April } & I & 171,10 & $\begin{array}{r}232,78 \\
\end{array}$ & 220,44 & memenuhi & 229,93 & memenuhi \\
\hline & II & 187,04 & $\begin{aligned}-229,85 \\
\end{aligned}$ & 218,77 & memenuhi & 226,20 & memenuhi \\
\hline \multirow{2}{*}{ Mei } & $I$ & 154,80 & $\begin{array}{l}207,69 \\
\end{array}$ & 154,23 & tidak memenuhi & 194,98 & memenuhi \\
\hline & II & 133,93 & $\begin{array}{l}189,33 \\
\end{array}$ & 156,65 & memenuhi & 165,96 & memenuhi \\
\hline \multirow{2}{*}{ Juni } & I & 153,64 & - 164,24 & 126,63 & tidak memenuhi & 154,88 & memenuhi \\
\hline & II & 102,98 & 147,96 & 127,98 & memenuhi & 131,99 & memenuhi \\
\hline \multirow{2}{*}{ Juli } & I & 91,36 & $\begin{array}{l}-105,21 \\
-\end{array}$ & 68,16 & tidak memenuhi & 92,06 & memenuhi \\
\hline & II & 82,96 & $\begin{array}{r}-93,48 \\
\end{array}$ & 98,09 & tidak memenuhi & 99,52 & tidak memenuhi \\
\hline \multirow{2}{*}{ Agustus } & I & 65,79 & 80,46 & 15,69 & tidak memenuhi & 79,43 & memenuhi \\
\hline & II & 57,92 & $\begin{array}{l}86,42 \\
\end{array}$ & 70,96 & memenuhi & 78,32 & memenuhi \\
\hline \multirow{2}{*}{ September } & I & 46,17 & $\begin{array}{l}85,56 \\
\end{array}$ & 23,92 & tidak memenuhi & 77,62 & memenuhi \\
\hline & II & 60,86 & . 72,34 & 49,79 & tidak memenuhi & 63,53 & memenuhi \\
\hline \multirow{2}{*}{ Oktober } & I & 57,73 & $\begin{array}{l} \\
\end{array} 85,51$ & 70,85 & memenuhi & 85,11 & memenuhi \\
\hline & II & 57,07 & $\begin{array}{l}-77,82 \\
\end{array}$ & $-86,69$ & tidak memenuhi & 62,08 & memenuhi \\
\hline \multirow{2}{*}{ November } & I & 61,08 & $\begin{array}{l}-128,37 \\
\end{array}$ & 104,45 & memenuhi & 105,34 & memenuhi \\
\hline & II & 61,60 & $\begin{array}{l}0109,51 \\
-\end{array}$ & 91,45 & memenuhi & 103,73 & memenuhi \\
\hline \multirow{2}{*}{ Desember } & I & 132,50 & $\begin{array}{l}-177,42 \\
\end{array}$ & 10,66 & tidak memenuhi & 162,18 & memenuhi \\
\hline & II & 167,02 & - 246,92 & 209,21 & memenuhi & 212,56 & memenuhi \\
\hline
\end{tabular}
debit andalan yang dapat digunakan pada Sungai Komering adalah perhitungan menggunakan distribusi Log Pearson karena nilai peluangnya lebih banyak memenuhi jika dibandingkan dengan distribusi Gumbel.

Tabel 27. Rekapitulasi Debit Andalan Terhadap Distribusi dan Peluang

Sumber : Hasil Perhitungan (2012) 


\section{Kesimpulan}

1. Berdasarkan analisa debit banjir, distribusi yang dapat digunakan untuk memprediksi debit banjir di Sungai Komering adalah distribusi Gumbel dengan perkiraan debit banjir untuk masingmasing kala ulang yaitu kala ulang 2 tahun sebesar $1.007,57 \mathrm{~m}^{3} / \mathrm{dt}$, kala ulang 5 tahun sebesar $1.459,79 \mathrm{~m}^{3} / \mathrm{dt}$, kala ulang 10 tahun sebesar $1.759,20 \mathrm{~m}^{3} / \mathrm{dt}$, kala ulang 25 tahun sebesar 2.137,50 $\mathrm{m}^{3} / \mathrm{dt}$, kala ulang 50 tahun sebesar $2.418,15 \mathrm{~m}^{3} / \mathrm{dt}$, dan kala ulang 100 tahun sebesar 2.696,73 m³/dt.

2. Berdasarkan analisa debit andalan menggunakan Metode Bulan Dasar Perencanaan, distribusi Log Pearson III dapat dipakai untuk menganalisis debit andalan di Sungai Komering karena variasi debit terlalu besar sehingga nilai debit andalan yang dihasilkan lebih banyak memenuhi dibandingkan dengan metode Gumbel. Debit andalan tertinggi terdapat pada bulan April periode II (15 harian kedua) yaitu sebesar 226,20 $\mathrm{m}^{3} / \mathrm{dt}$ dan debit andalan terendah terdapat pada bulan Oktober periode II (15 harian kedua) yaitu sebesar $62,08 \mathrm{~m}^{3} / \mathrm{dt}$.

\section{DAFTAR PUSTAKA}

[1] Haan, Charles T.,2002, Statistical Methods in Hidrology, Second Edition, Iowa State Press, Iowa.

[2] Montarcih Limantara, Lily, 2010, Hidrologi Praktis, Lubuk Agung, Bandung.

[3] Soemarto, C.D., 1999, Hidrologi Teknik. Edisi Kedua, Erlangga, Jakarta.

[4] Soewarno, 1995, Hidrologi : Aplikasi Metode Statistik untuk Analisa Data, Penerbit NOVA, Bandung.

[5] Wilson, E.M., 1993, Hidrologi Teknik. Edisi Keempat, Penerbit ITB, Bandung. 